\title{
THE EFFECT OF STEEL PLATE ON THE DEFLECTION OF SELF COMPACTED REINFORCED CONCRETE BEAM WITH AND WITHOUT OPENING
}

\author{
Ali Sabah AL-Amili \\ Engineering Collage, Al- Mustansirya University \\ (Received:17/5/2011; Accepted:11/3/2012)
}

\begin{abstract}
In this work aims at studying the influence of steel plate on the deflection of self- compacted reinforced concrete beams was investigated experimentally in this study to know the flexural behavior of these beams. Eight simply supported reinforced concrete beam were tested under the action of two point loads. The deflections of the beams with and without plate are measured. The steel plates of thickness $(3 \mathrm{~mm})$ with dimensions $(170 \times 350 \mathrm{~mm})$ were used. These plates were sticked on the concrete beams using epoxy. The steel plate inside the beam was sticked with and without epoxy (epoxy type EP), while the beams were taken with and without opening (10 mm diameter). The results show that the plate increased the capacity of the beam by increased the value of failure load. Hence, the beam with internal plate with epoxy increased the failure load by $34.2 \%$ than beam without plate , and $24.6 \%$ than beam with internal plate without epoxy, and $19.7 \%$ than beam with external plate with epoxy .
\end{abstract}

\section{1-INTRODUCTION}

Steel plate is become a practical alternative construction part in various structural aspects. It can be used externally to improve the flexural and shear capacities of beams ${ }^{(1)}$, while the epoxy-bonded steel plate is been used effectively in the world to increase the loadcarrying capacity of the reinforced concrete beam ${ }^{(2)}$.

In the construction of modern buildings, a network of pipes and ducts is necessary to accommodate essential services like water supply, sewage, air-conditioning, electricity, telephone, and computer network. Usually, these pipes and ducts are placed underneath beam soffit and, for aesthetic reasons, are covered by a suspended ceiling, thus creating a dead space. Passing these ducts through transverse openings in the beams lead to a reduction in the 
dead space and results in a more compact design. For small buildings, the savings thus achieved may not be significant, but for multistory buildings, any saving in story height multiplied by the number of stories can represent a substantial saving in the total height, length of air-conditioning and electrical ducts, plumbing risers, walls and partition surfaces and overall load on the foundation. ${ }^{(3)}$

In this thesis, the effect of steel plate on the deflection of self compacted reinforced concrete beam with and without opening is taken, while the Self-compacting Concrete (SCC) has been described by EFNARC ${ }^{(4)}$ as Concrete that is able to flow under its own weight and completely fill the formwork, even in the presence of dense reinforcement, without the need for any vibration, whilst maintaining homogeneity.

\section{2- SELF-COMPACTED CONCRETE}

Self- compacted concrete was developed around 1988 in Japan, to improve the durability of concrete structures. The early stage deteriorations of concrete structures are results of the manual placing and the inadequate consolidation. Therefore, the need for development of concrete with high fluidity and no segregation was felt. For several years, the problem of the durability of concrete structures has been a major problem posed to engineers.

To make durable concrete structures, sufficient compaction is required. Compaction for conventional concrete is done by vibrating. Over vibration can easily cause segregation. If steel is not properly surrounded by concrete it leads to durability problems. The answer to the problem may be a type of concrete which can get compacted in to every corner of formwork and gap between steel, purely by means of its own weight and without the need for compaction. The SSC concept can be stated as the concrete that meets special performance and uniformity requirements that cannot always be obtained by using conventional ingredients, normal mixing procedure and curing practices ${ }^{(5)}$.its important to test whether the concrete is self-compactable or not and also to evaluate deformability or viscosity for estimating proper mix proportioning if the concrete dose not have sufficient self- compact actability. The existing procedures for self- compacting characteristics are those, which measure height different points under free flow and also resistance against blocking. There is some test to show whether the concrete is self- compacted or not these test are ${ }^{(6)}$ :

a-Slump flow Test for measuring flow ability.

b-V- Fannel Test.

c- U-Type Test. 


\section{d-L- Box Test.}

e- Fill Box Test.

J- Ring Combination Test.

h- GTM segregation test.

i- Orimet $\backslash J$-ring combination Test.

In our study a ready mix for SCC were used and the V-Fannel, U-Type and L-box tests were used to found the content of our mixtures.

\section{2-1Mix design}

Self- compatibility can be largely affected by the characteristics of materials and the mix proportion. A rotational mix design method for SCC using a variety of materials is necessary. The mixed design as proposed is ${ }^{(7)}$ :

A- Coarse aggregate content is fixed at $50 \%$ of the solid volume,

B- Fine aggregate content is fixed at $40 \%$ of the mortar volume,

C- Water powder ratio in volume is assumed as 0.9 to 1.0 depending on the properties of the powder, the self- and

D- Super plasticizer dosage and the final water- powder ratio are determ determined so as to ensure compatibility.

\section{3- GENERAL DESCRIPTION OF BEHAVIOR FOR BEAMS LOADED IN TWO LOADS}

To obtain a general understanding of the behavior of concrete beams, all beams were simply supported on a clear span, and they were subjected to two concentrated loads symmetrically placed about the midspan ${ }^{(8)}$.The beams were incrementally loaded to failure.

After each increment of the load, the deflection at midspan were measured. The same loading rate was used for all beams.

The ACI code requirements for reinforcing sections are adopted in this study ${ }^{(9)(10) .}$ The stirrups distribution is very important to prevent the shear failure, and then the flexural failure is done. The flexural behavior is adopted in this study by get the failure load. 


\section{3-1 EXPERIMENTAL WOR}

In this study, eight reinforced self compacted concrete beams with dimensions $(1100 \mathrm{x}$ 180x $180 \mathrm{~mm}: \mathrm{L} \times \mathrm{b} \times \mathrm{h}$ ) were used. These beams has an opening with diameter of $(10 \mathrm{~mm})$ for circular opening as shown in Fig.(1). The tested beams were reinforced with steel bars with diameter (12 mm). Four bars for each beam were used, where two as longitudinal tension reinforcement. Stirrups of diameter $(6 \mathrm{~mm})$ were used with spacing for each tested beam as shown in Fig. (1).

On the other hand, the beam samples, were strengthened by thin steel plates of ( $3 \mathrm{~mm}$ ) thickness externally contacted with beam by epoxy, and internally with and without epoxy with same contacted in beam as in Fig.(2). Twenty four hours after pouring, the beams were stripped from moulds and cured in water containers for twenty eight days. The beams were removed from the water containers and then tested. The tested beams were simply supported over an effective span of $(1000 \mathrm{~mm})$ and loaded with two point loads as shown in Fig. (2).

The applied loads were distributed across the entire width using steel bars under hydraulic jack. The two point loads were applied gradually until the cracks were developed on the beam surface.

Concrete cubes were tested to find the compressive strength for beams and the average value for these cubes was (42 MPa) for twenty eight days curing. Eight beams were tested as shown in Table (2):

The diameter of circular opening was taken $(100 \mathrm{~mm})$, and the stirrups spacing was constant in all beams. The dimension of the plates and thickness were constant in all the beams.

The changes in plate site with and without epoxy and opening are taken as a parametric study.

\section{4- DISCUSSION OF THE RESULTS AND CONCLUSIONS}

The curves Fig. (3) to Fig.(5) give a good picture of the behavior of reinforced concrete self compacted beams with and without opening when external and internal plate was used.

Fig.(3) show the relation between load and deflection for beams without opening with external and internal plate. The results show that when the plate was used, the beam with internal plate with epoxy (BB3) increased the failure load by $34.2 \%$ than beam without plate in (BB1) and $24.6 \%$ than beam with internal plate without epoxy (BB4) and $19.7 \%$ than beam with external plate (BB2).This behavior was showing that the plate was increasing the 
capacity for beam, and the position of the plate when be outside the beam (external plate) give difference behavior when the plate inside the beam (internal plate). The plate inside the beam (internal plate) with epoxy give more capacity to the beam since, the contact with the concrete was increased, therefore, the value of failure was larger than when the plate without epoxy.

Fig.(4) show the load -deflection curves with external and internal plate (with opening).The results show, that the beam (BB7) with internal plate with epoxy gave the load failure larger than in (BB5) by $29.1 \%$, while this failure load was larger than the failure load in (BB8) and (BB6) by $19.4 \%$ and $9 \%$ respectively.

Fig.(5), from (a) to (C) gave the behaviors of the beams with and without opening with effect of plate. This figure shows the values of failures were increased when the beams without opening since, the opening decrease the capacity of beam.

The Appendix of Photo of experimental work is showing in this thesis.

\section{4-1-CONCLUSIONS}

From Fig ( 3) to Fig.(5), it is found that:

1. The plate increased the capacity of the beam by increased the value of failure load. Hence, the beam with internal plate with epoxy (BB3) increased the failure load by $34.2 \%$ than beam without plate in (BB1) and 24.6\% than beam with internal plate without epoxy (BB4) and 19.7\% than beam with external plate (BB2).

2. For beam with opening the same behavior was done (like the behavior for beam without opening). Hence, the beam (BB7) with internal plate with epoxy gave the load failure larger than in (BB5) by $29.1 \%$, while this failure load was larger than the failure load in (BB8) and (BB6) by 19.4\% and 9\% respectively.

3. The failure loads in beams without opening (BB1, BB2, BB3 and BB4) were larger than them in beams with opening (BB5, BB6, BB7 and BB8) by $(28.3 \%, 18.6 \%$, $23.4 \%$ and $14.6 \%$ ) respectively.

4. The beams with external plate has the failure load larger than the case when beam with internal plate with epoxy. Since, beam (BB2) has failure load larger than the failure load in beam (BB4) by 6\% for beams without opening. For beams with opening, the failure load for beam (BB6) was larger than the failure load in beam (BB8) by $11.4 \%$. 


\section{5- REFERENCES}

1. An, W., Saadatmanesh, H., and Ehsani, M. R.,"R/C beams strengthened with FRP plate. II: Analysis and parametric study." J. Struct. Eng., ASCE, (1991),pp. 111-117.

2. Dussek, I. J.. "Strengthening of bridge beams and similar structures by means of epoxy-resin-bonded external reinforcement." Transport. Res. Rec. 785, Transportation Research Board, (1980),pp. 21-24.

3. Mansur, M. A. "Design of Reinforced Concrete Beams with Web Openings" proceedings of the $6^{\text {th }}$ Asia pacific structural engineering and construction conference (APSEC2006),Kuala Lumpur, Malaysia. September 2006,pp. 5-6

4. EFNARC, Specification and Guidelines for Self-Compacting Concrete. London, UK: Association House, February 2002, pp.32-34.

5. P. Kumar, " Self- Compacting Concrete: Methods of Testing and Design" Journal of Advanced Concrete Technology, Vol.86,February 2006 ,pp.145-149.

6. Hajime O. Kamura and Masahiro Ouchi, " Self- Compacting Concrete" Journal of Advanced Concrete Technology, Vol.1,No.1,April 2003, pp.5-15.

7. Jacob ,Hansen and Tomny Baek, " Self- Compacting Concrete Based on White Portland Cement" Concrete Plant International World Wide, February 2006, pp.84-93.

8. Nabil F. Grace and Wael F. Ragheb and George Abdel Sayed, "Flexural and Shear Strengthening of Concrete Beams Using New Triaxially Braided Ductile Fabric" ACI Structural Journal, Vol.(100),No.(6), November 2003,pp.804-815.

9. Angelo D. Ambrisi and Filip C. Filippou, "Modeling of Cyclic Shear Behavior in Reinforced Concrete Members", Journal of Structural Engineering, Vol.(125), No.(10), October 1999, pp.1143-1150.

10. ACI Committee 318 " Building Code Requirements for Structural Concrete (ACI 318M08) ", American Concrete Institute, Detroit, USA, 2008. 
Table (1): Mix design used for self- compacted reinforced concrete

\begin{tabular}{|cc|}
\hline Used materials & Amount content \\
\hline \hline cement & $550 \mathrm{~kg} / \mathrm{m}^{3}$ \\
Coarse aggregate & $832 \mathrm{~kg} / \mathrm{m}^{3}$ \\
Fine aggregate & $825 \mathrm{~kg} / \mathrm{m}^{3}$ \\
Water/ cement ratio & 0.21 \\
Super plasticizer \%from weight of cement content & $9.5 \%$ \\
\hline
\end{tabular}

Table (2): Beams with details.

\begin{tabular}{|lll|}
\hline Beam no. & Details with plate & details with opening \\
\hline BB1 & Beam without plate & without opening \\
\hline BB2 & Beam with external plate & without opening \\
\hline BB3 & Beam with internal plate with epoxy & without opening \\
\hline BB4 & Beam with internal plate without epoxy & without opening \\
\hline BB5 & Beam without plate & with opening \\
\hline BB6 & Beam with external plate & with opening \\
\hline BB7 & Beam with internal plate with epoxy & with opening \\
\hline BB8 & Beam with internal plate without epoxy & with opening \\
\hline
\end{tabular}




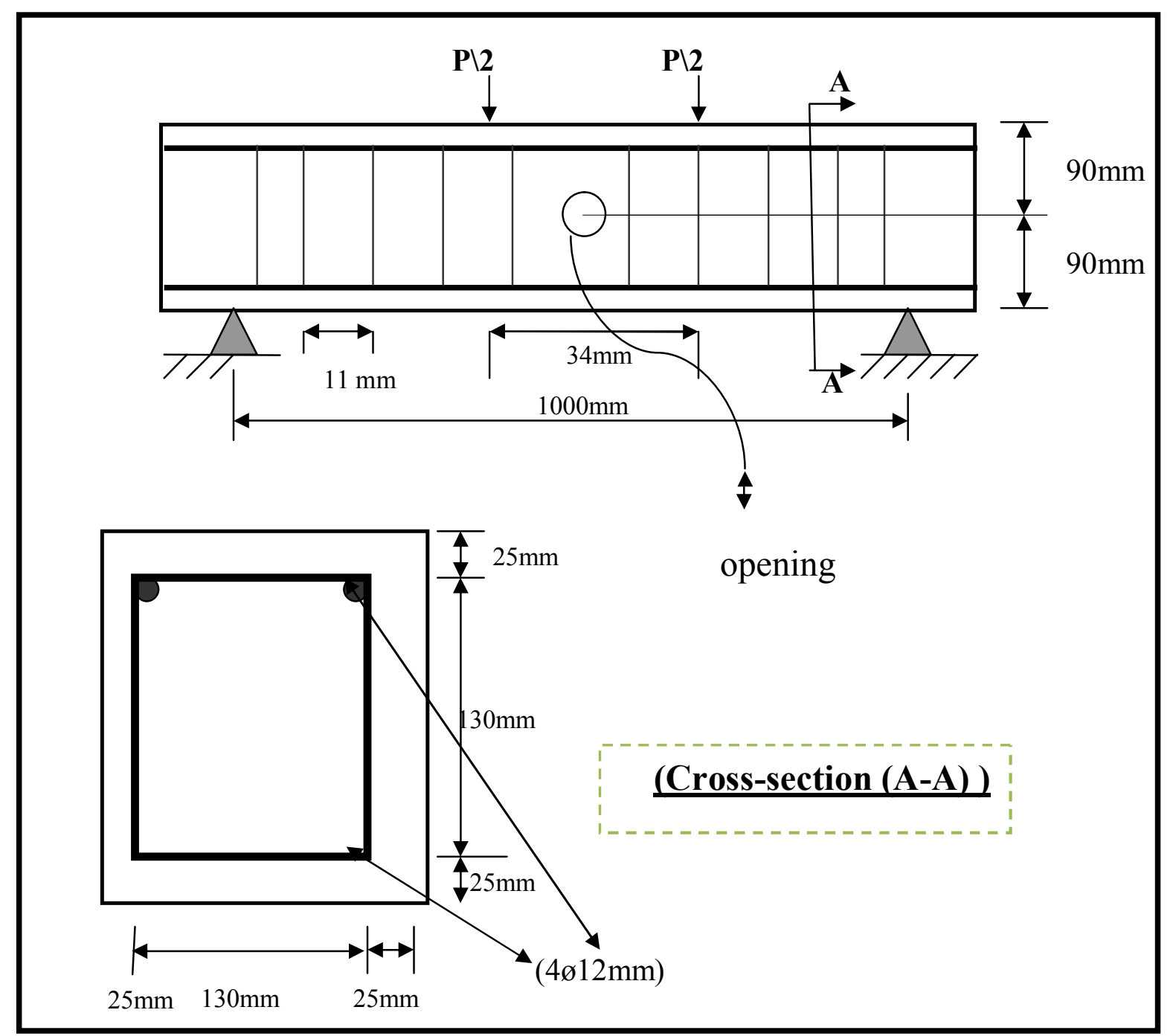

Fig. (1): The tested reinforced concrete beam with and without opening. 

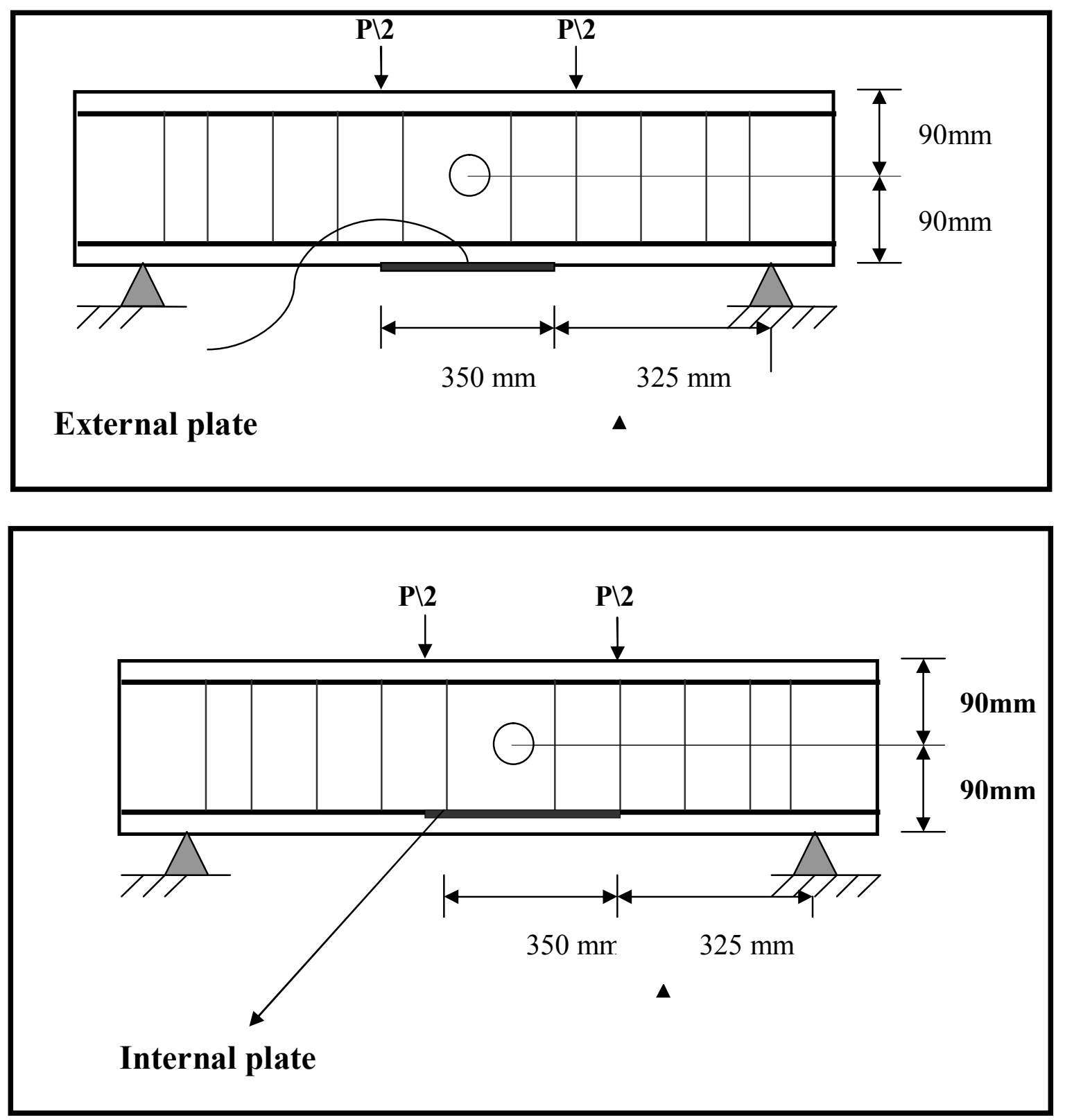

Fig. (2): Reinforced concrete beams with external and internal plate. 


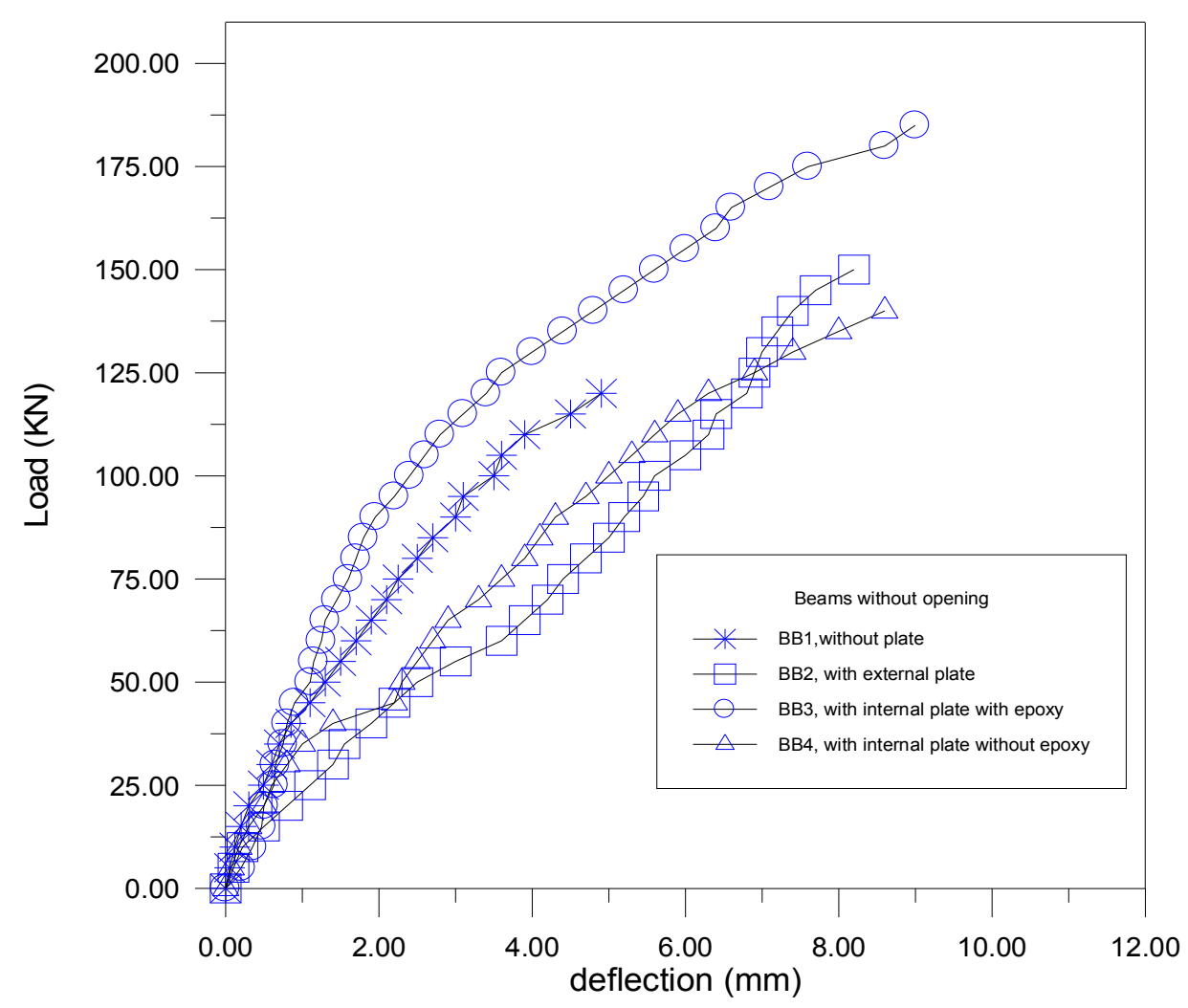

Fig.(3): Load-deflection curves for beams without opening (with external and internal plate).

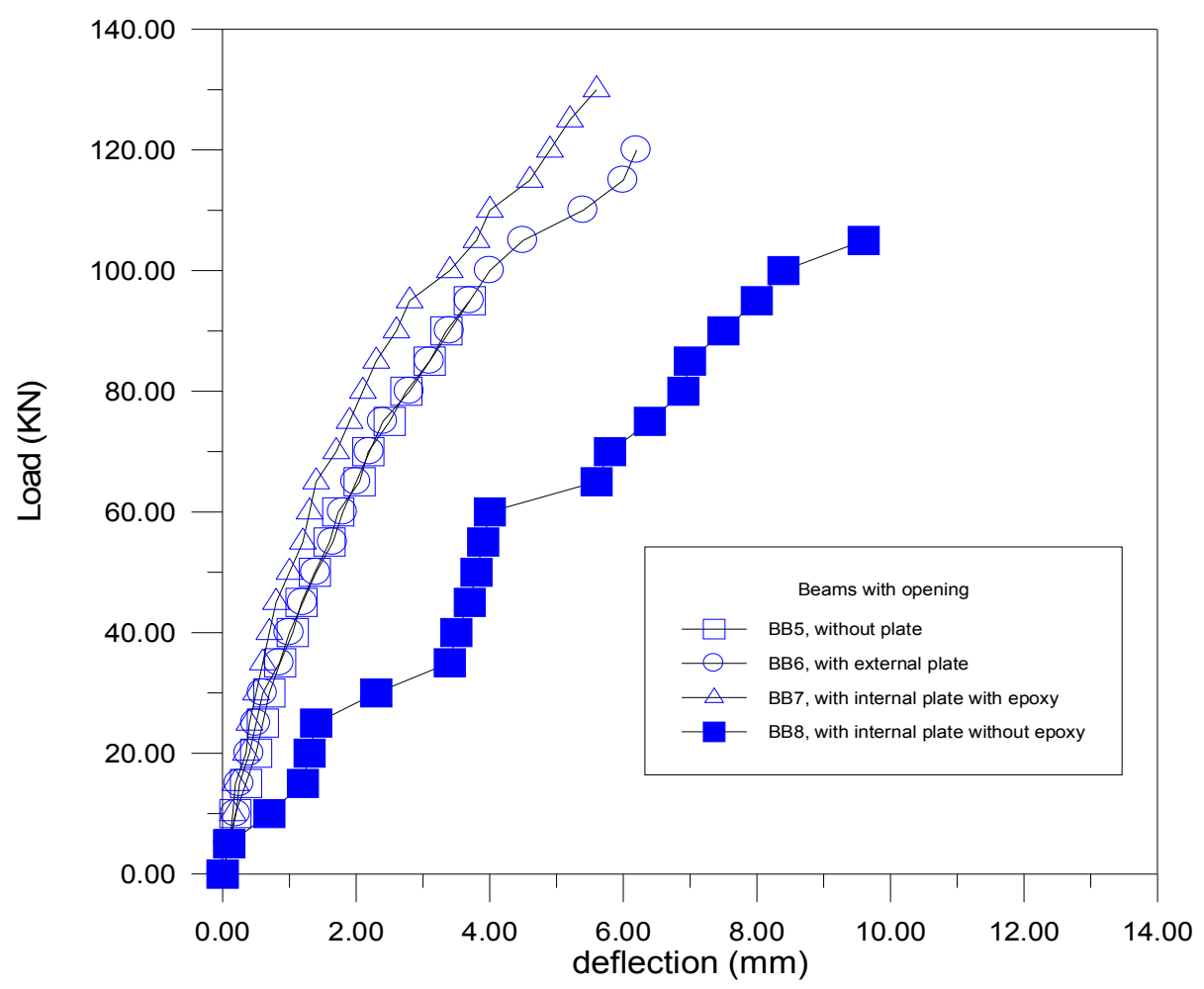

Fig.(4): Load-deflection curves for beams with opening (with external and internal plate). 


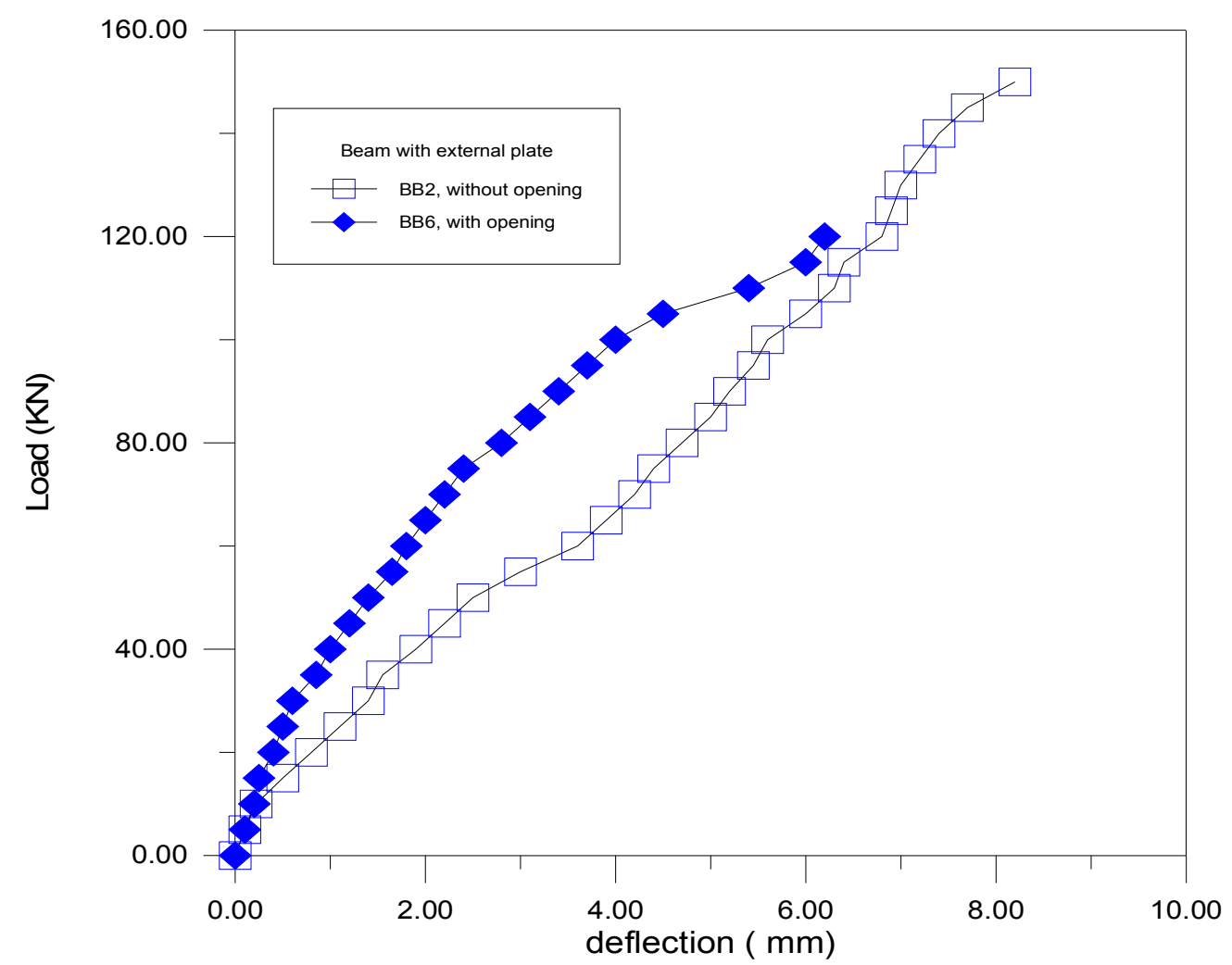

Fig. (5-a): with external plate.

Fig.(5): Load-deflection curves for beams with and without opening, from (a) to (c).

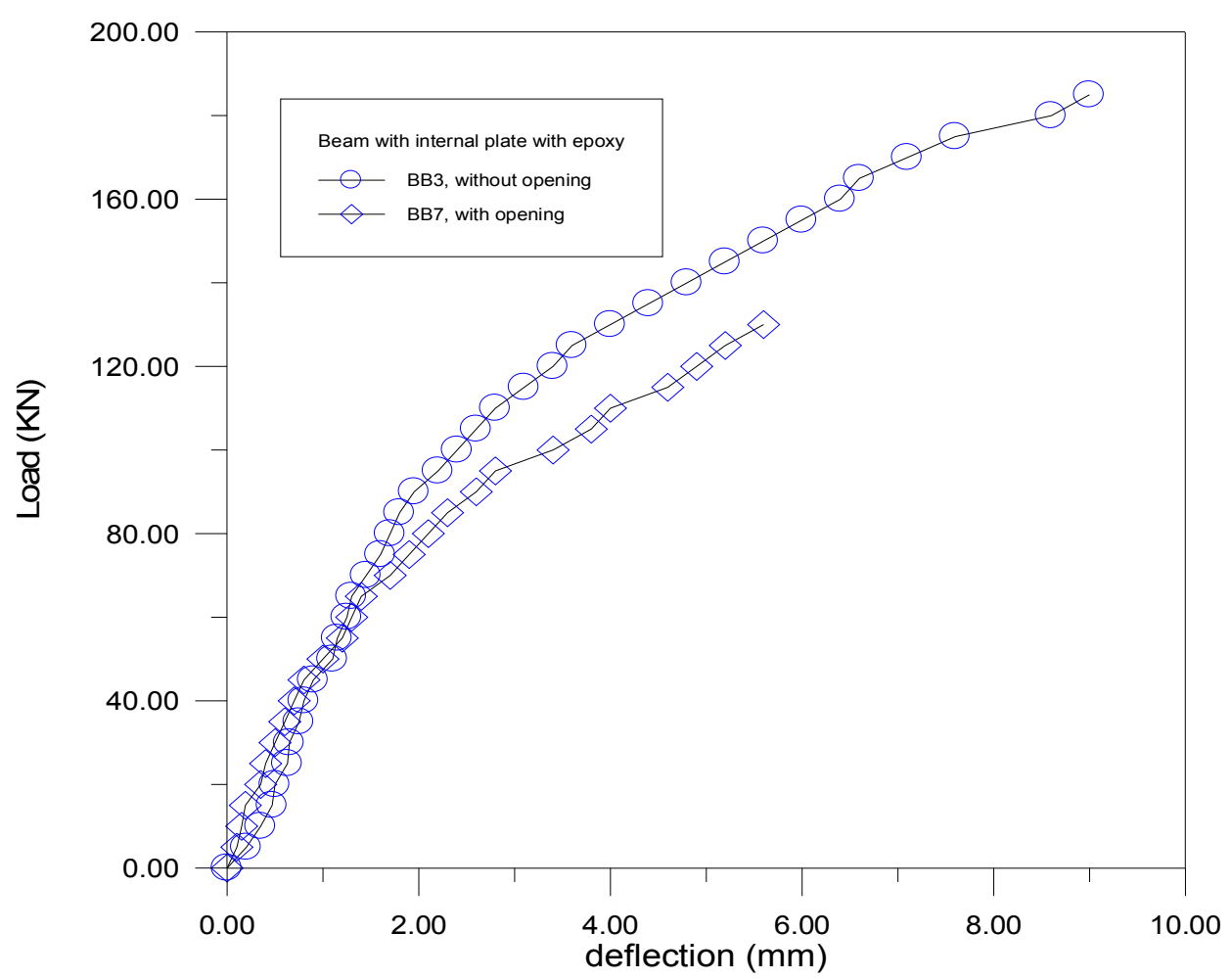

Fig. (5-b): with internal plate with epoxy. 


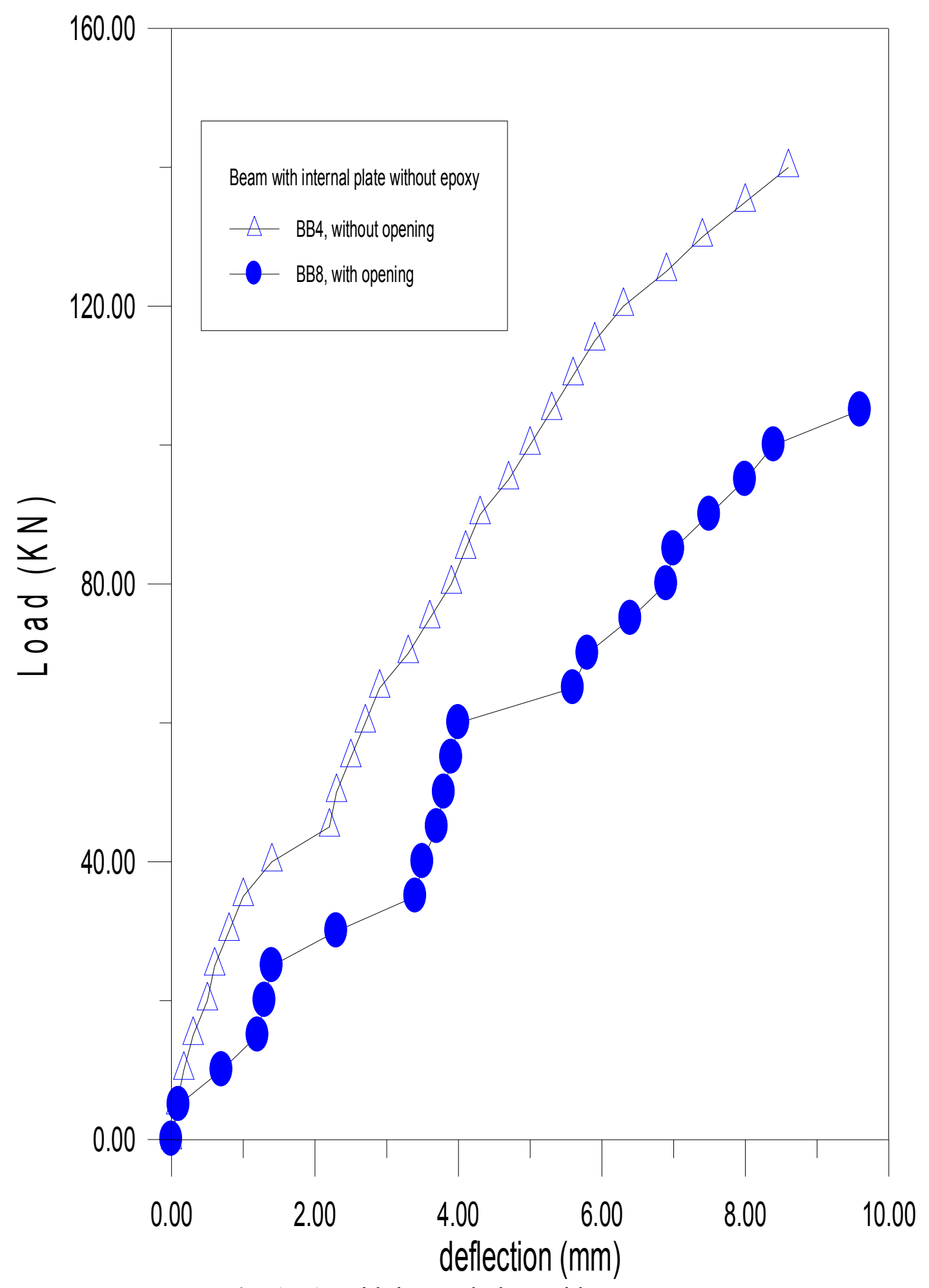

Fig. (5-c): with internal plate without epoxy. 


\section{APPENDIX OF PHOTO OF EXPERIMENTAL WORK}

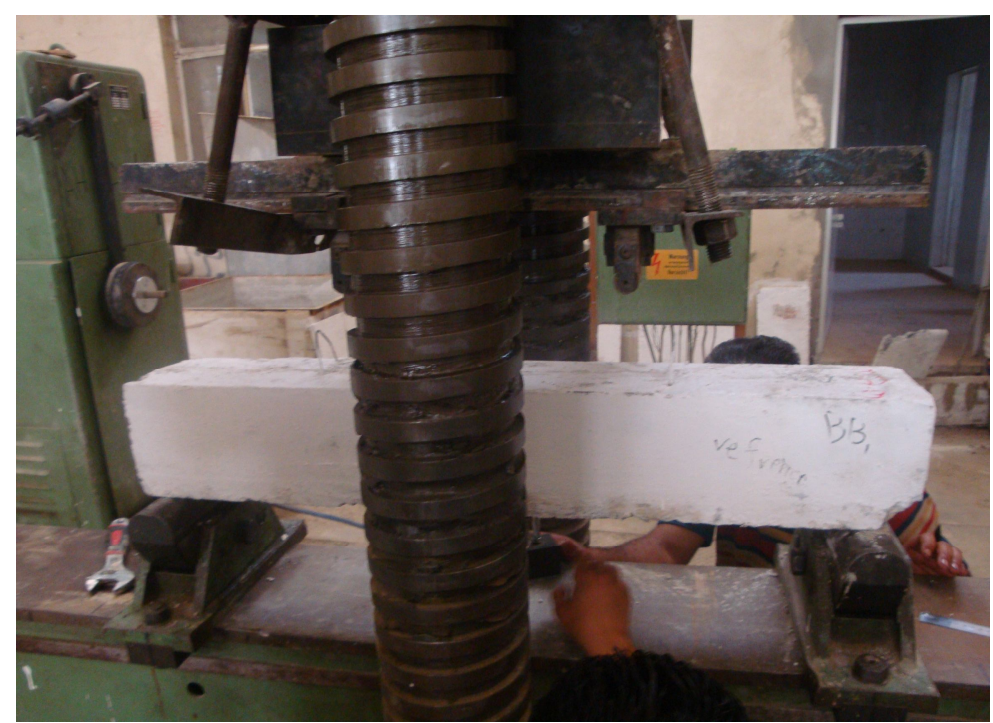

The machine applied load on the beam.

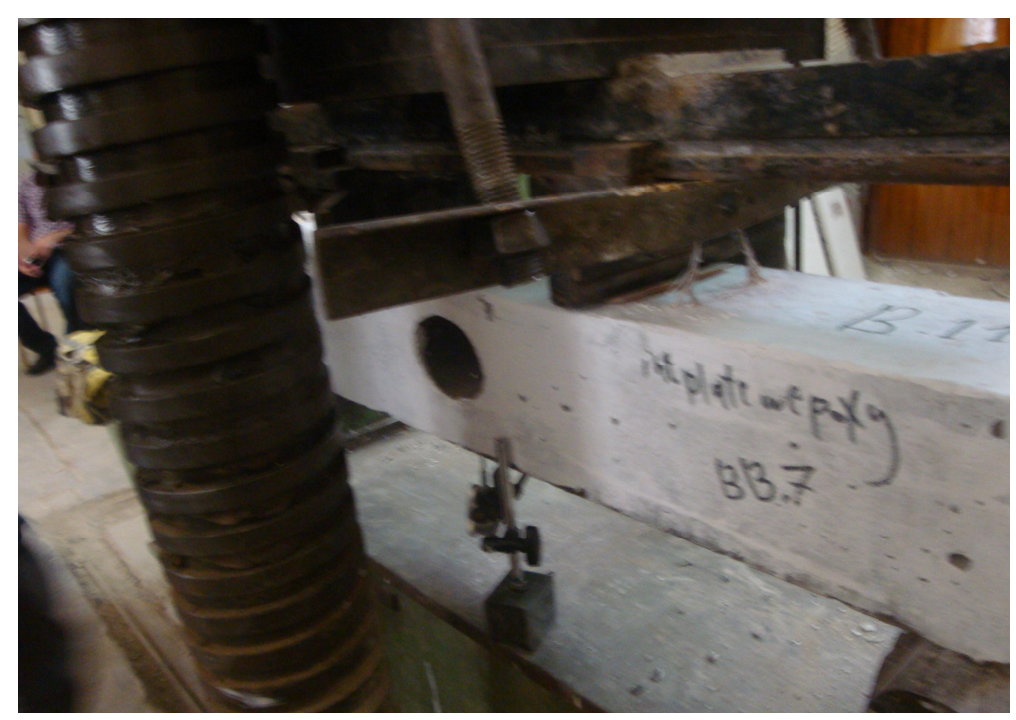

The beam with opening with machine.

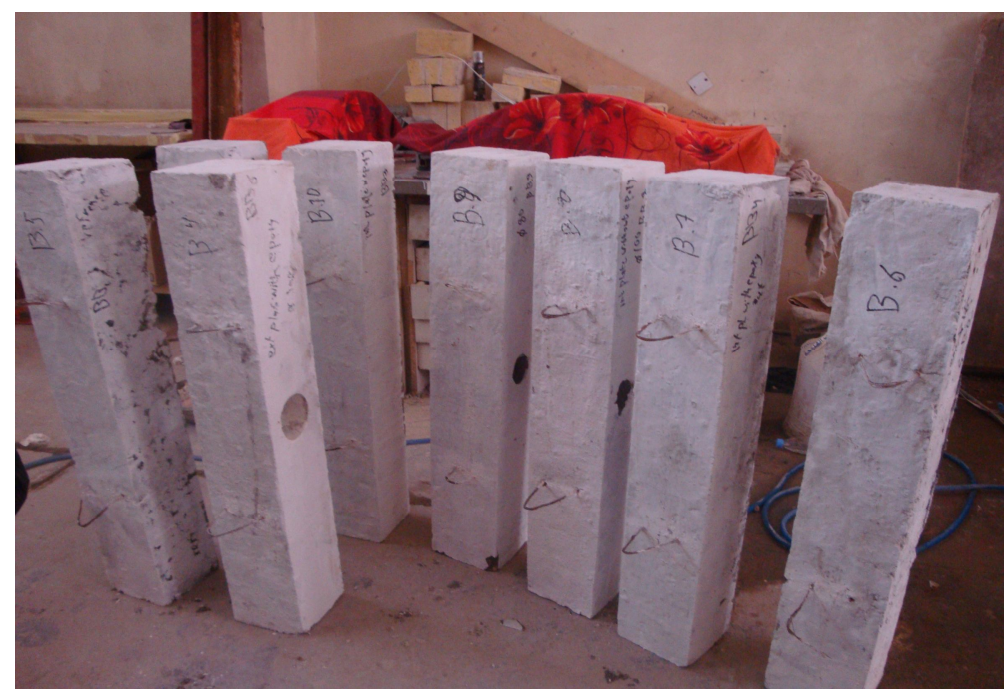

The beams 


\title{
تأثير لوح الحديد على فثل العتبات الخرسانية المسلحة ذاتية الرص مع أو بدون القتحات
}

\author{
علي صباح احمد \\ مدرس \\ كلية الهندسة - الجامعة المستتصرية
}

الخلاصة

يقدم هذا البحث دراسة عملية لتاثير لوح الحديد على فثل العتبات الخرسانية المسلحة ذاتية الرص لمعرفة سلوك الانحناء لهذه العتبات للهذا الغرض فقد اعتمدت في هذه الدراسة ثمانية نماذج. جميع هذه النماذج بسيطة الإسناد واختبرت

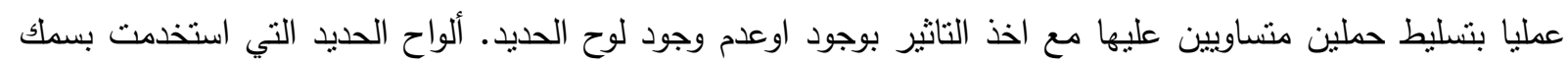

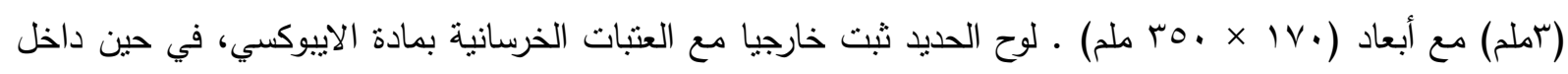

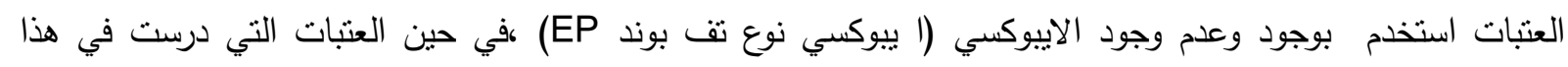
البحث اخذت بوجود وعدم وجود الفتحات (قطر · ل ملم). النتائج نظهر بان لوح الحديد يزيد من التحمل للعتبة من خلال

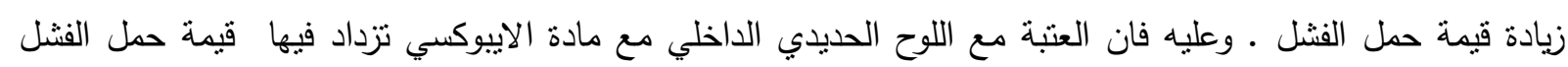

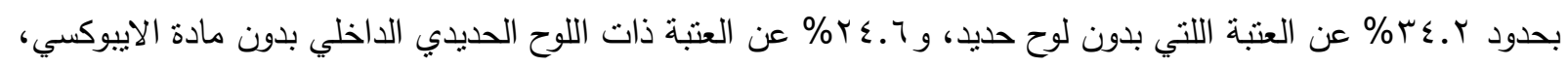
و و 19.V\% عن العنبة ذات اللوح الخارجي مع مادة الايبوكسي. 